$\begin{array}{ll}\text { Abstracta Iranica } & \begin{array}{l}\text { Abstracta Iranica } \\ \text { Revue bibliographique pour le domaine irano-aryen }\end{array} \\ & \text { Volume } 26 \mid \mathbf{2 0 0 5} \\ & \text { Comptes rendus des publications de } \mathbf{2 0 0 3}\end{array}$

"A New Source on the Early History of the Barìd".
Al-Abhath, 50-51, (2002 - 2003), pp. 121-134.

Antoine Borrut

Q OpenEdition

12 Journals

Édition électronique

URL : http://journals.openedition.org/abstractairanica/2711

ISSN : 1961-960X

Éditeur :

CNRS (UMR 7528 Mondes iraniens et indiens), Éditions de l'IFRI

Édition imprimée

Date de publication : 15 mai 2005

ISSN : 0240-8910

Référence électronique

Antoine Borrut, « «A New Source on the Early History of the Barīd ». Al-Abhath, 50 - 51, (2002 - 2003),

pp. 121-134. », Abstracta Iranica [En ligne], Volume 26 | 2005, document 210, mis en ligne le 08 décembre 2005, consulté le 25 septembre 2020. URL : http://journals.openedition.org/

abstractairanica/2711

Ce document a été généré automatiquement le 25 septembre 2020.

Tous droits réservés 


\section{«A New Source on the Early History of the Barīd ». Al-Abhath, 50 - 51, (2002 - 2003), pp. 121-134.}

\section{Antoine Borrut}

Cet article est tiré de la thèse de l'A. : The Origins and Early Development of the Islamic Postal System (al-Barīd) until ca. 846 CE, Cambridge University, 2002. Les éléments relatifs au Barīd trouvent un écho limité dans les sources pour ce qui est de la période prémamluke. L'A. présente ici une source inédite, les Siyāsat al-Mulūk (l'existence de ce texte avait été signalée par J. Sadan, "A New Source for the Buyid Period ", Israel Oriental Studies, 9, (1979), pp. 355-376), qui livre un matériau important sur le sujet. L'A. propose une édition et une traduction des passages les plus significatifs : l'un consacré aux attributs requis pour exercer les fonctions de scribe dans le Dīwān al-Barìd, l'autre offrant des aspects pratiques des procédures postales. L'un des points mis en avant dans le texte réside dans la fonction clef que jouent les services postaux en matière de renseignement. Signalons en complément les travaux de Y. Ragheb, Les messagers volants en terre d'Islam (Paris, CNRS Éditions, 2002) et « La transmission des nouvelles en terre d'Islam. Les modes de transmission ", in : La circulation des nouvelles au Moyen Âge, XXIV $^{\text {e }}$ Congrès de la S.H.M.E.S. (Avignon, juin 1993), École Française de Rome, 1994, pp. 37-48.

\section{INDEX}

Thèmes : 4.1. Histoire médiévale 
AUTEURS

ANTOINE BORRUT

IFPO - Damas 